\title{
KNOWLEDGE SOURCES IN L2 LEARNING
}

Diana Ayliff

Nelson Mandela Metropolitan University

Should one bother to teach grammar to second language (L2) learners of English? The purpose of this article is to examine the hypothesis that there is an interface between explicit and implicit knowledge sources. Three groups of learners at the Nelson Mandela Metropolitan University were asked to articulate, first without a prompt and then with a prompt, the grammatical rules they were applying to correct common errors. The test results suggest that there is a high correlation between what they seemingly know implicitly and the hidden, possibly previously explicit knowledge source on which they are drawing. The article concludes by discussing some of the theoretical implications of the research.

\section{INTRODUCTION}

The relationship between language teaching, on the one hand, and language acquisition and learning on the other, has long been a topic of research. The study reported in this article explores the concept of knowledge sources in second language (L2) learning. The study extends the research that was previously described in an article (Ayliff, 2006) in which the relationship between explicit and implicit knowledge of rules of grammar amongst L2 learners of English was investigated.

As in that article the term explicit knowledge, indicates learned knowledge that can be explicitly stated as in articulating rules of grammar; while the term implicit knowledge refers to knowledge acquired unconsciously as in acquiring a first language. Some authors (Brumfit, 1984; Krashen, 1981; Widdowson, 1978) have argued that formal instruction of grammar does little to develop L2 language acquisition and the L2 is best "picked up" spontaneously through exposure to it. Krashen (1985) does acknowledge that the learning of formal grammar may assist in the production of accurate language (especially in writing) where the so-called monitor can intervene. In Krashen's system there is no interface between what is learned and what is acquired in spontaneous production and learners will proceed through the same basic interlanguage stages irrespective of the type of instruction they have been given.

On the other hand, some authors (Cook, 2001; Doughty, 1991; Ellis, 1995; Williams and Evans, 1998) have suggested that in order to attain high levels of proficiency, the learners need to focus on form, and furthermore, that there is an interface between learned and acquired knowledge. The implication of these suggestions is that what was originally explicit, learned knowledge may become implicit, acquired knowledge which may be used spontaneously in both spoken and written language. 
The purpose of the research presented in this article is twofold: firstly, to explore the relationship between these (possibly) different knowledge sources; and secondly, whether what had previously been learned by focusing on form in the classroom has influenced the learners' L2 language ability at a later stage in their interlanguage. It is an area of debate that has provoked much controversy in L2 studies, and the question regarding the extent to which form-focused instruction is beneficial to L2 classroom learning will, no doubt, long continue to be debated.

This present study thus aimed to prove that there is an interaction between explicit and implicit knowledge, in that explicit knowledge may, with practice, become implicit knowledge.

\section{RESPONDENT GROUPS}

Three groups of respondents from the Nelson Mandela Metropolitan University participated in the study:

- Group 1 was a group of 140 that had almost completed a semester course in Practical English in which they had been taught by means of a form-focused approach. All the respondents in this group had passed English L2 at grade 12 level.

- Group 2 was a group of 64 third year education students following an English course designed for students aiming to become teachers in the junior and intermediate phase (grades 1-7). All the respondents in this group had also passed English L2 at grade 12 level.

- Group 3 was a group of 60 first year students studying a professional / business course in English. Most of these students were planning to go into the legal profession. Amongst this group were the 27 English L1 respondents and the rest were L2 speakers of English, but they had passed English L1 at grade 12 level.

\section{PROCEDURE AND MATERIALS}

The respondents were required to do two tests:

- Test 1 consisted of twenty sentences, each of which contained a different common error made by L2 learners of English. The respondents were asked to correct the error and write down the explanation or rule which had been violated by the error.

- Test 2 consisted of the identical twenty sentences containing the same errors, but in this case, the respondents were also handed a list of 50 numbered grammatical rules, from which they had to choose a rule that identified the error.

Respondents were warned in the pre-test explanation that they would be expected to complete two tests. They were not told, however, that these tests were identical. Test 1 was distributed, and respondents had unlimited time to complete the test. Upon handing in test 1, respondents were given test 2, together with the rules list. Most respondents completed both tests in $40-$ 45 minutes, but took considerably less time doing the second test, than they had done doing the first.

The tests were always given to the respondents in the same order to ensure comparable results and to allow test 1 to act as a prime for test 2, that is to constitute the practice which makes implicit knowledge, explicit. It was also to test whether those respondents, who had had been 
taught by means of a form-focused approach, fared better at correcting and explaining which error was violated, than those in the other groups.

\section{RESULTS}

A summary of the success rate for the entire 20 questions is given in table 1 below.

Table 1

\begin{tabular}{|c|c|c|c|c|c|c|c|c|}
\hline & \multicolumn{3}{|c|}{$\begin{array}{c}\text { L2 English } \\
\text { at grade 12 level }\end{array}$} & \multicolumn{2}{c|}{$\begin{array}{c}\text { L1 English } \\
\text { at grade 12 level }\end{array}$} \\
\hline & $\begin{array}{c}\text { Practical English } \\
\text { Students } \\
\text { (group 1) }\end{array}$ & $\begin{array}{c}\text { Education students } \\
\text { (group 2) }\end{array}$ & \multicolumn{2}{c|}{$\begin{array}{c}\text { All L2 } \\
\text { (groups 1 \& 2 } \\
\text { combined) }\end{array}$} & \multicolumn{2}{c|}{$\begin{array}{c}\text { Prof./ Bus. Eng. } \\
\text { Students } \\
\text { (group 3) }\end{array}$} \\
\hline $\begin{array}{c}\text { Test 1 } \\
\text { Nest 2 }\end{array}$ & $\mathbf{6 4}$ & $\mathbf{6 4}$ & $\mathbf{1 4 0}$ & $\mathbf{1 4 0}$ & $\mathbf{2 0 4}$ & $\mathbf{2 0 4}$ & $\mathbf{6 0}$ & $\mathbf{6 0}$ \\
\hline $\begin{array}{c}\text { Correct } \\
\text { Rule } \\
\%\end{array}$ & 564 & 989 & 388 & 650 & 480 & 824 & 484 & 1019 \\
\hline $\begin{array}{c}\text { Correc- } \\
\text { tion } \\
\text { of error } \\
\%\end{array}$ & 16 & 1635 & 1113 & 1175 & 1373 & 1411 & 1870 & 1863 \\
\hline
\end{tabular}

\section{DISCUSSION OF RESULTS}

In a similar study conducted by Green and Hecht (1992) in which a correction and rule explanation test were used, it was assumed that if the respondents were unable to articulate the rules, but were able to correct the errors, they were using implicit knowledge. This study questions that assumption, because the reason respondents are unable to articulate the rules might not be that they lack explicit knowledge, but that it might be represented in a form that is difficult for the L2 learner to articulate. For instance, they might lack the metalanguage and the memory to do so. It might also be that they only half remember the rule and what they once had learned consciously, has now become procedural knowledge and represented in a different way to how it had been learned originally. Learners are displaying hidden knowledge by succeeding in correcting the errors, yet they are apparently not conscious of possessing this knowledge, i.e. they know more than they realize. They display this hidden knowledge, possibly previously explicit knowledge which has become implicit knowledge, in performance.

Test 2 in this study attempted to tap into this procedural knowledge by prompting the memory and assisting respondents to make explicit what had essentially become implicit. Table 1 shows that, while the scores for the correction task in the two tests remained fairly constant with very little variability in the answers given in both tests, the scores for the rule identification task improved dramatically. Group 1's scores jumped from a mean of $28 \%$ to a mean of $49 \%$, group 2 from a mean of $19 \%$ to a mean of $33 \%$, and group 3 from a mean of 
$24 \%$ to a mean of $51 \%$. This study suggests that there is an interface between explicit and implicit knowledge and that there is no sharp divide between them, but there is a sliding scale of degrees of explicit and implicit knowledge.

Tables 2 to 5 below show the relationship between the rules and corrections for all 20 questions in tests 1 and 2. The application of the Pearson chi-square test shows that in all cases the degree of probability $(\mathrm{p})$ that the correlation might be incorrect is below $1 \%$. Once again it is shown that, if the subjects are able to articulate a rule correctly, they are always able to produce a correct correction in test 1 . In test 2 , if the respondents picked the correct rule, they had a very high chance of being able to produce a correct correction. It would seem that, when prompted by being given a list of rules, they are able to recognize the rule they are applying to correct the sentence. This, in turn, suggests that the knowledge that was once explicit has become implicit, and may again become explicit if prompted. When prompted by the presentation of a list of rules the respondents are able to identify the rule and recognize that this is the rule which they had applied, albeit implicitly, until prompted by the list of rules, as in test 2. The learning of explicit rules is not, as Krashen (1981, 1985, 1994) suggests, merely peripheral. Learning explicit rules may assist learners in developing implicit knowledge of grammar.

\section{Table 2}

Relationship between rules and corrections for tests 1 and 2

\begin{tabular}{|l|l|c|c|c|c|c|c|}
\hline \multicolumn{7}{|c|}{$\begin{array}{r}\text { Practical English Respondents } \\
\text { L2 English at grade 12 level } \\
\text { (group 1) }\end{array}$} \\
\hline & \multicolumn{2}{|c|}{$\begin{array}{c}\text { Incorrect } \\
\text { Correction }\end{array}$} & \multicolumn{2}{c|}{$\begin{array}{c}\text { Correct } \\
\text { Correction }\end{array}$} & \multicolumn{2}{c|}{ Total } \\
\hline \multirow{2}{*}{ Test 1 } & $\begin{array}{l}\text { Incorrect } \\
\text { rule }\end{array}$ & 525 & $26.0 \%$ & 1498 & $74.0 \%$ & 2023 & $100 \%$ \\
\cline { 2 - 9 } & $\begin{array}{l}\text { Correct } \\
\text { rule }\end{array}$ & 2 & $0.3 \%$ & 785 & $99.7 \%$ & 797 & $100 \%$ \\
\hline Test 2 & $\begin{array}{l}\text { Incorrect } \\
\text { rule }\end{array}$ & 499 & $35.2 \%$ & 918 & $64.8 \%$ & 1417 & $100 \%$ \\
\cline { 2 - 9 } & $\begin{array}{l}\text { Correct } \\
\text { rule }\end{array}$ & 13 & $0.9 \%$ & 1370 & $99.1 \%$ & 1383 & $100 \%$ \\
\hline
\end{tabular}

Test 1: Pearson chi-square test: $(\chi 2=248.528, \mathrm{df}=1, \mathrm{p}<0.01)$

Test 2 Pearson chi-square test: $(\chi 2=550.282, \mathrm{df}=1, \mathrm{p}<0.01)$ 
Table 3

\begin{tabular}{|l|l|c|c|c|c|c|c|}
\hline \multicolumn{7}{|c|}{$\begin{array}{r}\text { Lducation Student Respondents } \\
\text { L2 English at grade 12 level } \\
\text { (group 2) }\end{array}$} \\
\hline \multirow{2}{*}{ Test 1 } & $\begin{array}{l}\text { Incorrect } \\
\text { Correction }\end{array}$ & \multicolumn{2}{c|}{$\begin{array}{c}\text { Correct } \\
\text { Correction }\end{array}$} & \multicolumn{2}{c|}{ Total } \\
& $\begin{array}{l}\text { Incorrect } \\
\text { rule }\end{array}$ & 566 & $54.8 \%$ & 467 & $45.2 \%$ & 1033 & $100 \%$ \\
\cline { 2 - 9 } & $\begin{array}{l}\text { Correct } \\
\text { rule }\end{array}$ & 0 & $0.0 \%$ & 247 & $100.0 \%$ & 247 & $100 \%$ \\
\hline \multirow{2}{*}{ Test 2 } & $\begin{array}{l}\text { Incorrect } \\
\text { rule }\end{array}$ & 480 & $55.6 \%$ & 383 & $44.4 \%$ & 863 & $100 \%$ \\
\cline { 2 - 9 } & $\begin{array}{l}\text { Correct } \\
\text { rule }\end{array}$ & 49 & $11.8 \%$ & 368 & $88.2 \%$ & 417 & $100 \%$ \\
\hline
\end{tabular}

Test 1: Pearson chi-square test: $\left(\chi^{2}=242.619, \mathrm{df}=1, \mathrm{p}<0.01\right)$

Test 2: Pearson chi-square test: $(\chi 2=223.143, \mathrm{df}=1, \mathrm{p}<0.01)$

Table 4

\begin{tabular}{|l|l|c|c|c|c|c|c|}
\hline \multicolumn{7}{|c|}{$\begin{array}{r}\text { L2 English Respondents Combined } \\
\text { (Education + Practical English) } \\
\text { (groups 1 and 2) }\end{array}$} \\
\hline \multirow{2}{|c|}{$\begin{array}{l}\text { Incorrect } \\
\text { Correction }\end{array}$} & \multicolumn{2}{c|}{$\begin{array}{c}\text { Correct } \\
\text { Correction }\end{array}$} & \multicolumn{2}{c|}{ Total } \\
\hline Test 1 & $\begin{array}{l}\text { Incorrect } \\
\text { rule }\end{array}$ & 1091 & $35.7 \%$ & 1965 & $64.3 \%$ & 3056 & $100.0 \%$ \\
\cline { 2 - 9 } & $\begin{array}{l}\text { Correct } \\
\text { rule }\end{array}$ & 2 & $0.2 \%$ & 1042 & $99.8 \%$ & 1044 & $100.0 \%$ \\
\hline \multirow{2}{*}{ Test 2 } & $\begin{array}{l}\text { Incorrect } \\
\text { rule }\end{array}$ & 979 & $42.9 \%$ & 1301 & $57.1 \%$ & 2280 & $100.0 \%$ \\
\cline { 2 - 9 } & $\begin{array}{l}\text { Correct } \\
\text { rule }\end{array}$ & 62 & $3.4 \%$ & 1738 & $96.6 \%$ & 1800 & $100.0 \%$ \\
\hline
\end{tabular}

Test 1: Pearson chi-square test: $(\chi 2=501.826, \mathrm{df}=1, \mathrm{p}<0.01)$

Test 2: Pearson chi-square test: $(\chi 2=825.566, \mathrm{df}=1, \mathrm{p}<0.01)$ 
Table 5

\begin{tabular}{|l|l|l|l|l|l|l|l|}
\hline \multicolumn{7}{|c|}{$\begin{array}{r}\text { Professional English Respondents } \\
\text { L1 English at Grade 12 level } \\
\text { (group 3) }\end{array}$} \\
\hline \multirow{2}{*}{\begin{tabular}{|l} 
Incorrect \\
Correction
\end{tabular}} & \multicolumn{2}{c|}{$\begin{array}{c}\text { Correct } \\
\text { Correction }\end{array}$} & \multicolumn{2}{c|}{ Total } \\
\hline \multirow{2}{*}{ Test 1 } & $\begin{array}{l}\text { Incorrect } \\
\text { rule }\end{array}$ & 80 & $8.4 \%$ & 875 & $91.6 \%$ & 955 & $100.0 \%$ \\
\cline { 2 - 9 } & $\begin{array}{l}\text { Correct } \\
\text { rule }\end{array}$ & 1 & $0.3 \%$ & 304 & $99.7 \%$ & 305 & $100.0 \%$ \\
\hline \multirow{2}{*}{ Test 2 } & $\begin{array}{l}\text { Incorrect } \\
\text { rule }\end{array}$ & 77 & $12.4 \%$ & 542 & $87.6 \%$ & 619 & $100.0 \%$ \\
\cline { 2 - 9 } & $\begin{array}{l}\text { Correct } \\
\text { rule }\end{array}$ & 7 & $1.1 \%$ & 634 & $98.9 \%$ & 641 & $100.0 \%$ \\
\hline
\end{tabular}

Test 1: Pearson chi-square test: $(\chi 2=24.898, \mathrm{df}=1, \mathrm{p}<0.01)$

Test 2: Pearson chi-square test: $(\chi 2=65.166, \mathrm{df}=1, \mathrm{p}<0.01)$

This study thus suggests that there is a complex "sliding" interaction on a continuum between explicit and implicit knowledge that is sometimes displayed in performance. Learners display hidden, previously explicit knowledge which had slid into the realm of implicit knowledge, when they succeed in correcting the errors, while apparently not being conscious of possessing this knowledge, i.e. they know more than they realise.

\section{SOME THEORETICAL IMPLICATIONS}

It might be useful to consider this study in the light of Bialystok's model (1994) of knowledge sources. Her theory differs from most other theories in that she believes that explicit knowledge can also be unconscious knowledge. She explores how knowledge is represented and how this representation changes as we mature and as our awareness and understanding of the world (including how language works) increases.

Bialystok (1994) theorises that universal categories of language, such as principles and parameters, are activated during a sensitive period. The language/s to which the person is exposed is/ are analysed and the parameters are set. This, for her, involves explicit knowledge, but this explicit knowledge is not conscious. Should learners later learn an L2 after the sensitive period they would find learning a language that employed the same categories easier than one that did not. Using example of Korean (1994: 563), which has no category for tense, Bialystok points out that, for Koreans, learning a language that does depend on that category will be more difficult than for another learner, who has analysed that concept during the sensitive period.

Implicit knowledge, according to her, 'is the endowment out of which language grows' and it cannot become explicit but 'remains buried deep in the Language representation' (1994: 567). There are, however, 'degrees' of explicitness and what may appear to be explicit knowledge 
that has become implicit is, in fact, simply explicit knowledge that has become easier to access, i.e. it has become automatized with practice.

Although I do not support Bialystok's notion that explicit knowledge can be unconscious, it might well be that there are different ways of knowing and that we acquire or learn these ways differently. These ways may change according to what, and when, something is being acquired or learned. With regard to language acquisition and learning, vital issues which influence these are whether the sensitive/ critical period is past and how close the L1 is to the L2.

Bialystok notes that 'rules make sense to adults; they make little difference to young children' (1994: 565), and it is significant that, at about the time (puberty) that the critical period comes to an end, the learner is at the age that rules begin to make sense. It is my hypothesis that L2 language learning is on a continuum of explicit through to implicit ways of knowing, and that what might be acquired implicitly during the critical period might later have to be learned explicitly. Ways of knowing the world - such as understanding concepts of volume, time or subjacency rules - are initially implicit and although 'known', are impossible to be articulated or made explicit. With greater maturity and more sophisticated cognitive powers, these implicit ways of knowing are slowly refined and become increasingly explicit.

In the research described in this article, it is probable that the mean for the rule identification increased so significantly in test 2 because some of the implicit knowledge was 'raised' to the point where it became explicit. By being reminded of a rule learned at an earlier stage, the respondents were able to 'raise' or 'access' that knowledge. Whether this knowledge was originally learned consciously (i.e. explicitly) and then, through practice, became automatised, or whether it was originally acquired implicitly and later (prompted by the rules in the test or learned as grammar rules in school) raised to the point of explicitness in the test, is not clear.

It seems likely that most of what we know in L2 is acquired implicitly, as there are some features of language that defy explanations that are understandable to the majority of L2 learners, but there is certainly much that can be learned after the critical period has passed. This learned, and initially explicit knowledge, may, with practice, slide down the explicit/ implicit scale to become increasingly implicit and automatized. The implications of this study are that Bialystok's ideas are supported and that it is not a waste of time to teach certain points of grammar to L2 learners of English.

Another implication of this study is that some rules are useful if learners are at the cognitive stage where they can apply them and later, with practice, internalize them. There seems to be an interface between explicit and implicit learning. Certainly the results of the two tests described in this article, and considered in the discussion above, indicate this. Some rules are difficult to apply and might best be left untaught. It would be a fruitless - and bizarre exercise to explain the mathematical and physical laws of how to retain one's balance on a bicycle. It is far easier to give the initiate a bicycle and demonstrate how it is done. With practice, success usually results. As Ellis (1994: 1) states, 'we learn to do them implicitly like swallows learn to fly', but that is just at the one end of the continuum. There is plenty of space on the continuum for explicit learning too, and when bicycle riders have mastered the basics and wish to enter races, it might well be advantageous for them to be taught some theory about aerodynamics and good racing techniques. In the same way, advanced L2 learners might well gain by being taught some theory about how the language they are attempting to learn works. 


\section{REFERENCES}

AYLIFF, D. 2006. An exploration of explicit and implicit learning of rules by English second language learners. Per Linguam, 22(2): 55-63.

BRUMFIT, CJ. 1984. Communicative methodology in language teaching. Cambridge: Cambridge University Press.

BIALYSTOK, E. 1994. Representation and ways of knowing: Three issues in second language acquisition. In Ellis, N (Ed.), Implicit and explicit learning of languages. London: Academic Press. 549-69.

COOK, V. 2001. Second language learning and language teaching. Third Edition. London: Hodder.

DOUGHTY, C. 1991. Second language instruction does make a difference: Evidence from an empirical study of SL relativization. Studies in Second Language Acquisition, 13 (4): 431- 69.

DOUGHTY, C \& J WILLIAMS (Eds) 1998. Focus on form in the classroom second language acquisition. Cambridge: Cambridge University Press.

ELLIS, N (Ed). 1994. Implicit and explicit learning of languages. London: Academic Press.

GREEN, PS \& K HECHT. 1992. Implicit and explicit grammar: an empirical study. Applied Linguistics, 13 (2): 168-84.

KRASHEN, SD. 1981. Second language acquisition and second language learning. Oxford: Pergamon.

KRASHEN, SD. 1985. The input hypothesis: Issues and implications. Harlow: Longman.

KRASHEN, SD. 1994. The input hypothesis and its rivals. In Ellis, N (Ed.), Implicit and explicit learning of languages. London: Academic Press.45-77.

WIDDOWSON, HG. 1978. Teaching language as communication. Oxford: Oxford University Press.

WILLIAMS, J \& J EVANS. 1998. What kind of focus and on which forms? In Doughty, C \& $\mathrm{J}$ Williams (Eds), Focus on form in the classroom second language acquisition. Cambridge: Cambridge University Press.139-155.

\section{BIOGRAPHIC NOTE}

Diana Ayliff teaches in the Department of Language and Literature at the Somerstrand Campus of the Metropolitan University. Her teaching interests include second language teaching, academic English and Victorian Literature. Her research interest is in second language teaching and acquisition. Diana.ayliff@nmmu.ac.za. 


\section{APPENDIX A}

\section{CORRECTION AND RULE TASK/S}
a) On the next page you will find twenty sentences written by students who are learning English. There is one mistake (underlined) in each sentence.
b) Write the correct form of the underlined phrase in the space provided. It is not necessary to write out the whole sentence.
c) In test 1 the respondents were asked to write a grammar rule that would help the student to avoid this mistake, while in test 2 they were asked to choose a grammar rule from a list.

c) If you can not think of (find - test 2) a rule, write a dash - (blank).

\section{EXAMPLES}

\begin{tabular}{|l|l|}
\hline $\mathbf{1}$ & $\begin{array}{l}\text { Its been raining again. } \\
\text { Correction: It's } \\
\text { Rule: It's stands for It is. You need an apostrophe to indicate the omission of } \\
\text { the letter } i .\end{array}$ \\
\hline $\mathbf{2}$ & $\begin{array}{l}\text { I have a belgian friend at university. } \\
\text { Correction: Belgian } \\
\text { Rule: Proper nouns need a capital letter. }\end{array}$ \\
\hline $\mathbf{3}$ & $\begin{array}{l}\text { In the course we was shown how to do spreadsheets. } \\
\text { Correction: were shown } \\
\text { Rule: }-\end{array}$ \\
\hline
\end{tabular}

The following sentences were taken from a letter of a Belgian student to an English friend.

1 As you know lives my cousin on a farm.

2 I spent last week-end with my cousin. Most of the time I've played soccer.

3 If you come to Brussels next year, $\underline{I}$ show you the new shopping mall.

4 It takes not very long to get there.

5 There is a farm near us. Do you like to ride horses?

6 If you do there'll be no problem, because I know the farmer for a long time.

7 Of course, we won't have to pay something for the ride.

8 Have I told you that my brother has got a new car? He drives more careful now than before.

The following sentences are taken from a statement given by a Belgian student who saw a man steal a cell phone in a shop in London.

9 About half an hour ago a man was coming into the shop.

$10 \mathrm{He}$ had a very big nose and smoked a cigarette.

11 While the shop-keeper was fetching a cell phone from the backroom, the man, which was a thief, snatched a little cassette-recorder from the counter and ran out of the shop.

12 Outside he was arrested by an policeman.

The following sentences are taken from a letter of a Xhosa student to an English friend.

13 Everything is going well here at NMMU, but, it is possible, that I am to decide to change my course next year. 
14 I don't like my English lecturer as she made me to rewrite the last two assignments!

15 The lecturer she is too strict.

16 She said that I to work harder.

17 There are about 110 students in our English class. That is too much students to have in one class.

18 I bumped into my old boyfriend, Mxolisi, at the rag bash. She is doing well at the Technikon.

19 Mxolisi told me he have just completed his second year successfully.

20 I'll sign off now as I am to be going to bed early as I'm very tired. 